tions. The aim of this work was to determine the influence of aerodynamic separation in process sorting-calibration of single-component seed mixes.

The researches were carried out after the example of such corn hybrids, for which sorting-calibration determines out-put and quality of production considerably. Hybrids of Institute selection - Ushitskey 167 SV, Pyatihatskey 270 SV, Borozenskey 277 MV, Soloninskey 298 SV, Zbruch were studied. For studying of quality the methods ДCTУ 4138 were used, and also methods, which were worked out in Institute for corn seeds. A single-component mix was got after cleaning of seeds in form a sawing group of triage and walk through the main sieve in depend on hybrids.

It's established peculiarities of aerodynamic separation in process of seeds treatment, in which it was carried out cleaning and formed a sawing group. It was exposed instability of separation in connection with changing in air stream indexes of windage of seed mix in depend on its place and position, and also its speed and air density. In air stream seeds of hybrids were distributed by influence of their form, size, capacity, weight of 1000 seeds and at least of all - by specific surface and weight (capacity). In this connection, aerodynamic separation it is recommended to use on a primary stage for seed cleaning, and on a secondary stage - for sorting-calibration to use more deeper sieve and gravitational separation on appropriate machines. On the base of findings it was worked out variational curve of aerodynamic distribution of single-component seed mix.

Key words: corn, seeds, quality and put-out, methods of separation.

\title{
REFERENCES
}

1. M. A. Telengator et al. Treatment of seed cereals. Moscow: Kolos, 1972, p. 271.

2. O. S. Vorontsov Elevator industry, grain-drying and grain-cleaning. Moscow: Kolos, 1974, p. 432.

3. N. Y. Kurpa "Principles and methods of separation of grain mass", in Storage and treatment of grain, Dniepropetrovsk, 2011 № 4(142), pp.33-36.

4. Separated machines “Almaz”/http:www.info@agrotech.lg.ua

5. N. Y. Kurpa "Air separation of corn seed and methods of determination of its parameters" in Selection and seed farming. M. Y. Kurpa and S. A. Skotar. Kharkov. № 101. 2012. pp. 239-246.

6. Seeds of agricultural crops. Methods of determination quality: SSU 4138-2002. [Acted since 2004-01-01]. Kiev. Derzhspozhuvstandart of Ukraine. 2003., p. 173.

7. E. D. Kazakov. Methods of evaluation seed quality. Moscow. Agropromizdat, 1987., p. 215.

8. A. N. Repin. Methods of cold sprouting of corn seeds in Bul. VSRI of corn, A. N. Repin and A. I. Naumenko. № 5-6., pp. 55-58.

9. E. M. Lebid et al. Methods of carrying out field experiments with corn: methodical recommendation. Dniepropetrovsk. 2008., p. 27.

10. P. F. Kupreev. "The results of research process pneumoseparetion of seed legy-mes "in P. F. Kupreev et al. Perfectiong of after-harvesting treatment and storage of seeds in collective farms and state farms, collection of scientific works. Moscow. 1984. № 10. pp. 45-48.

$$
\begin{aligned}
& \text { Надійшла 23.01.2016. Додруку 13.02.2016 } \\
& \text { Адреса для переписки: } \\
& \text { вул. Канатна, 112, м. Одеса, } 65039
\end{aligned}
$$

УДК 662.767.2 : [633.18 : 631.576.4] : 637.5 - 027.332

Г.В. КРУСІР, професор, д-р техн.. наук, завідуюча кафедрою ЕтаПT, Heinz LEUENBERGER* Dr., Prof., О.О. ЧЕРНИШОВА, аспірант кафедри ЕтаПТ

Одеська національна академія харчових технологій *Університет прикладних наук Північно-західної Швейцарії

\section{ДОСЛІДЖЕННЯ СУМІСНОЇ УТИЛІЗАЦІЇ РИСОВОЇ ЛУЗГИ ТА ВІДХОДІВ М'ЯСОПЕРЕРОБНИХ ВИРОБНИЦТВ МЕТОДОМ АНАЕРОБНОГО ЗБРОДЖУВАННЯ}

\footnotetext{
Анотація

Основні положення стратегії політики з охорони навколишнього середовища та забезпечення сталого розвитку краӥни передбачають комплексне вирішення проблем збалансованого розвитку економіки краӥни та поліпшення стану навколишнього середовища. Сучасні темпи розвитку зернопереробної та м'ясопереробної галузей роблять все більш актуальними питання ефективних та економічно вигідних шляхів утилізаиії відходів виробнищтв. Відповідно до принциипів концепџіі повторної обробки сировинних відходів особливої уваги потребує утилізація відходів м'ясопереробної галузі, до яких відносяться стічні води, щ⿻о утворюються безпосередньо під час виробничтва м'ясної продукиї̈, та гній з цехів передзабійного утримання ВРX (великої рогатої худоби). Перспективним напрямком утилізаиї відходів харчових виробництв вважають біотехнологічні методи переробки. Одним з таких методів є анаеробне зброджування, щя являє собою безперервний багатокомпонентний процес перетворення органічних речовин до кінцевих продуктів - біогазу з вмістом метану, парів води та вуглекислого газу, яке забезпечується роботою різних мікробіальних співтовариств.
} 
Метою даної роботи було дослідження спільної утилізачії рисової лузги, гною ВРХ та стічних вод м'ясопереробного підприємства (СВ МПП) шляхом анаеробного зброджування в лабораторному анаеробному UASB біореакторі (Upflow Anaerobic Sludge Blanket reactor) періодичної дї на протязі 10 днів. Під час дослідження виділені параметри впливу складу субстрату на ефективність розкладання органічних речовин, утворення біогазу та вихід метану у результаті анаеробних реакцій. Проведено низку експериментів анаеробного зброджування субстратів з різним ваговим співвідношенням гною ВРХ, СВ та рисової лузги при мезофільному температурному режимі $\left(36 \pm 1{ }^{\circ} \mathrm{C}\right)$. У результаті дослідження визначено ступінь деструкиії органічних речовин гною ВРХ та рисової лузги і оцінено негативний вплив жирних кислот на протікання анаеробних реакиій з метою виділення оптимальних вагових пропориій складників змішаних відходів у якості субстрату для зброджування в анаеробному біореакторі. Була доведена ефективність використання змішаних субстратів для отримання метану та збільшення ступеня біорозкладання органічних речовин відходів у порівнянні з показниками зброджування моносубстратів.

Ключові слова: анаеробне зброджування, відходи, рисова лузга, гній ВРХ, біогаз.

\section{Вступ}

Одною 3 стратегічних напрямків розвитку харчової та переробної промисловості, які забезпечують у необхідній кількості населення харчовими продуктами, є активна екологізація підприємств. А саме, враховуючи світові темпи зростання цін на харчову сировину, питання подальшого зменшення та ефективної утилізації відходів харчових та переробних виробництв набувають актуальності як в екологічному, так і в економічному плані. На сьогодні модернізація виробничих потужностей та переведення виробництва на замкнутий цикл розглядається як один $з$ фундаментальних напрямків у вирішенні питань раціонального використання природносировинних ресурсів та охорони навколишнього середовища. Вимоги сучасного ринку диктують необхідність впровадження у процес виробництва технологій з низькою енерго-, ресурсо- і капіталоємністю, що дозволяють випускати якісну і конкурентноспроможну продукцію. Поступово виробники звертаються до накопиченого вітчизняного та зарубіжного досвіду з утилізації відходів, яке передбачає утворення вторинних продуктів, тим самим забезпечуючи додатковий прибуток та покращення екологічного іміджу підприємства. Цим аспектам приділяють значу увагу підприємства, продукція яких $є$ орієнтована на європейський споживчий ринок.

За даними статистичного щорічника державної служби статистики України за останні роки [1], урожайність рису в Україні становила 50 ц 31 га. 3 Одеської області у період 2014-2016 p.p. на переробні підприємства надходить у середньому 4,5 тис.т рису за рік, тим самим забезпечуючи утворення відходів рисової лузги у середньому в кількості 828 т щорічно. Існують три основні способи утилізації рисової лузги: спалення, створення спеціальних відвалів та переробка з подальшим отриманням кремнієвих сполук. Враховуючи відносно невеликі обсяги вирощування та переробки рису в Україні, домінуючим методом утилізації відходів рису залишається спалювання, що не відповідає сучасним вимогам маловідходних та безвідходних технологій. Що стосується темпів розвитку м'ясопереробної галузі та тваринництва загалом, то за період 2014-2016 р.р. кількість поголів'я ВРХ по Україні становить 3884 тис.голів за рік, з яких приблизно 192 тис.голів вирощують та переробляють в Одеській області. Таким чином обсяги утворення відходів тваринництва та м'ясопереробних підприємств в Україні та Одеській обл. становить: гній ВРX за стійловий період (220240 днів) - 34,9 млн.т та 1,7 млн т відповідно, усере- днені дані питомої витрати СВ - 188,8 млн м ${ }^{3}$ та 3,76 млн м ${ }^{3}$ за рік відповідно. Виходячи 3 цього, поліпшення рентабельності підприємств зернопереробної та м'ясопереробної галузі шляхом ефективної утилізації відходів з подальшим отриманням вторинних продуктів $є$ пріоритетним напрямком розвитку політики підприємств у питанні поводження з відходами.

Вибір методів утилізації здійснюють, враховуючи фізико-хімічні параметри самих відходів, особливість підприємства, еко- та енергоефективність. Рисова лузга представляє собою продукт лущення зернової культури - рису, характеризується значним вмістом клітковини та мінеральних речовин. Гній BPX - це суміш екскрементів тварині сечі, перемішаний з солом'яною або торф'яною підстилкою, за видами поділяється на підстилковий (твердий) та безпідстилковий (рідкий) гній. Склад гною залежить від таких параметрів, як порода, вік тварин, вид кормів та тип підстилки. Стічні води м'ясопереробних підприємств є багатокомпонентними та висококонцентрованими за ХСК (хімічне споживання кисню), БСКповн (біогогічне споживання кисню протягом 20 днів), вмістом зважених речовин і жирів, мають підвищений вміст біогенних елементів, нейтральні значення $\mathrm{pH}$, температуру в межах 20-30 ${ }^{\circ} \mathrm{C}$, органічні речовини знаходяться у колоїдній і розчинній формax.

Анаеробне зброджування вважається одним 3 найбільш ефективних шляхів утилізації багатокомпонентних субстратів. Біохімічні та мікробіологічні аспекти процесу анаеробного зброджування залежать від складних умов, що виникають у процесі розвитку різних мікробіальних співтовариств 3 одночасним протіканням відповідних біологічних реакцій, що, як правило, специфічні до субстратів. Основними факторами впливу на процес анаеробного зброджування субстрату у реакторі $\epsilon$ температура, рівень $\mathrm{pH}$, вміст поживних речовин, токсичних речовин, летких жирних кислот, важких металів, ліпідів та вуглеводів, часу гідравлічного утримання, швидкості потоку субстрату та навантаження на мул.

Протікання анаеробних реакцій у значній мірі залежать від температури середовища з причини чутливості до температурних стрибків мікробіальних співтовариств анаеробної системи. Існують три різні температурні діапазони, при яких забезпечується ріст та функціонування (життєдіяльність) анаеробних бактерій: психрофільний $\left(18-20^{\circ} \mathrm{C}\right)$, мезофільний $(25-$ $\left.40^{\circ} \mathrm{C}\right)$, і термофільний $\left(50-70^{\circ} \mathrm{C}\right)$. Відомо, що при дотриманні психрофільного режиму процес зброджування субстратів проходить дуже повільно та не за- 
безпечує достатній ступінь деструкції органічних речовин. Під час мезофільного режиму забезпечується стабільний ріст метаногенних бактерій, що збільшує приріст біомаси та позитивно впливає на біорозкладання компонентів субстрату. Дотримання термофільного температурного режиму в реакторі стимулює більш інтенсивне протікання процесів анаеробного зброджування, порівняно з вище зазначеними, однак, витрати на енергію для підігріву та підтримання термофільного температурного режиму не компенсуються у повному обсязі за рахунок утворення біогазу з реактору, що забезпечує додаткові витрати.

Діяльність мікробіальних співтовариств залежить також від рівня $\mathrm{pH}$, так як кожна група мікроорганізмів, що бере участь у процесі, має специфічні рівні $\mathrm{pH}$ для оптимального росту. Контроль параметpy $\mathrm{pH} \epsilon$ одним 3 фундаментальних параметрів для підтримки оптимального росту бактерій. Відомо, що акумуляція летких жирних кислот у біореакторі спричиняє різкі стрибки рівня $\mathrm{pH}$, що стає причиною послідовного відмирання метаногенів, що у свою чергу, призводить до зменшення ефективності видалення забруднюючих речовин та утворення біогазу [2]. Оптимальний рівень $\mathrm{pH}$ для ацитогенних бактерій становить від 5,2 до 6,5 од. $\mathrm{pH}$, в той час коли оптимальний рівень $\mathrm{pH}$ середовища для метаногенів варіює від 7,5 до 8,5 од. $\mathrm{pH}$. Оптимальним рівнем $\mathrm{pH}$ робочого середовища реактору вважають 6,8-7,3 од. $\mathrm{pH}$, за таких умов не відбувається надмірного накопичування летких жирних кислот і не спостерігається значних змін у прирості біомаси.

Важливим аспектом у регулюванні роботи біореактору $є$ наявність поживних речовин, які $є$ важливими для ефективного росту анаеробних мікроорганізмів [3]. Додатково до основного вмісту макронутрієнтів, тонка організація мікробіального співтовариства потребує наявності мікронутрієнтів та мікроелементів, таких як Азот, Фосфор, Сульфур, Калій, Кальцій, Магній, Залізо, Нікель, Кобальт, Цинк та Мідь для забезпечення оптимального росту. Ці поживні речовини повинні бути присутні у дуже низьких концентраціях, однак, їх відсутність взагалі негативно впливає на ріст та життєдіяльність мікроорганізмів.

Наявність іонів амонію відіграє важливу роль у анаеробному зброджуванні. Для оптимального протікання процесу анаеробного зброджування рівень іонів амонію повинен підтримуватись на рівні 80 мг/л. Відомі дослідження стабільного протікання анаеробних процесів зброджування 3 вмістом іонів амонію за мезофільних умов на рівні 50-150 мг/л, більш високі концентрації амонію призводили до серйозних порушень роботи реактору через зниження темпів росту та специфічної активності метаногених бактерій [4]. Крім того, для стабільного росту метаногенних організмів необхідна відповідна кількість сульфіду, але слід зауважити, що залежно від рівня pH реакційного середовища, сульфіди можуть проявляти токсичні властивості. Численні дослідження показали, що токсичність сульфіду проявляється по відношенню до метаногенів, а саме до ацетатспоживачів та $\mathrm{H}_{2}$-споживачів, які інактивують та пригнічують перетворення проміжних продуктів до кінцевих, цей процес залежить від акумуляції летких жирних кислот, що спричиняє подальше зниження виходу метану.

3 літературних даних відомо, що присутність важких металів у субстраті у багатьох випадках спричиняе токсичний або інгібуючий ефект на протікання процесу анаеробного зброджування. Однак, незважаючи на це, їх присутність у дуже низьких («слідових») концентраціях необхідна для росту мікроорганізмів. Науковцями було оцінено токсичність важких металів (Кадмій, Хлор, Мідь, Нікель та Цинк), за результатами дослідження виявлено, що ацидогенні, ацетогенні та метаногенні мікроорганізми характеризуються різною резистентністю до токсичного впливу важких металів [6].

\section{Матеріали та методи досліджень}

Експериментальні дослідження виконано шляхом зброджування субстратів у біореакторі з висхідним потоком рідини крізь шар анаеробного мулу UASB (Upflow Anaerobic Sludge Blanket reactor) періодичної дії загальним об'ємом у 50 дм $^{3}$ (рис.1). Досліджено анаеробне зброджування субстратів з різним ваговим співвідношенням компонентів у мезофільних умовах за температурним режимом $36 \pm 1^{\circ} \mathrm{C}$ та $\mathrm{pH}$

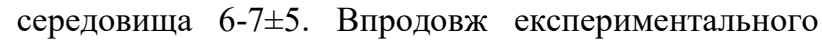
дослідження контролювались показники кількісті виділеного біогазу і метану, що утворились, ступінь біорозкладання органічних речовин за показником хімічного споживання кисню (ХСК) та $\mathrm{pH}$ середовища.

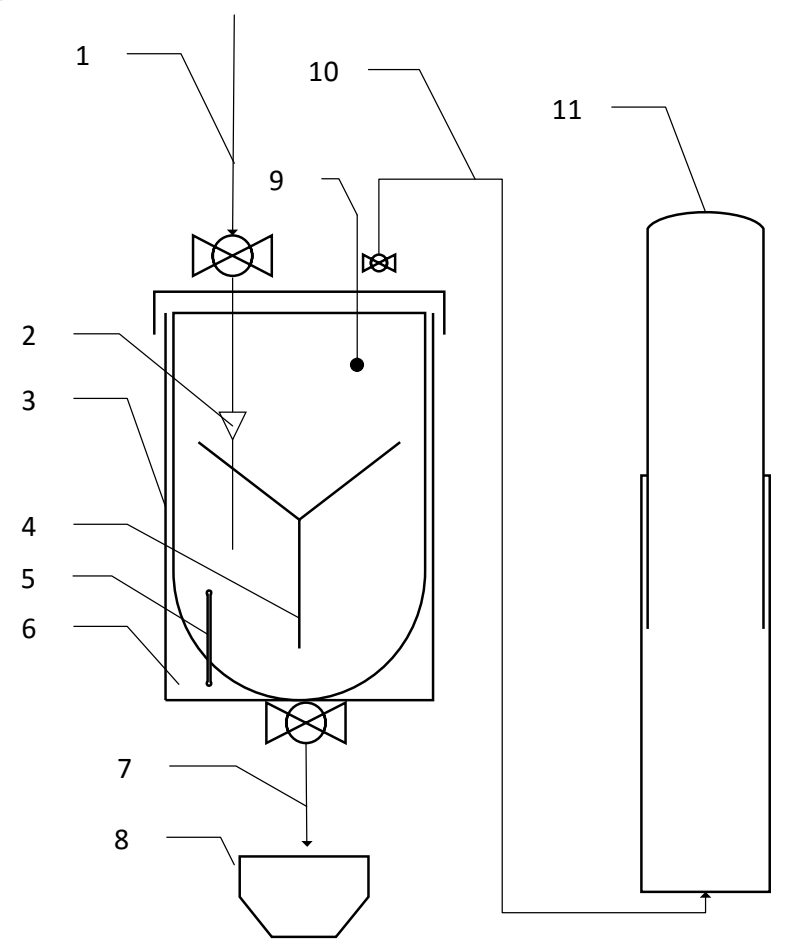

Рис. 1 - Апаратуро-технологічна схема анаеробного зброджування стічних вод 1 - подача CB; 2 -потік CB; 3 -біореактор; 4 -електрична мішалка; 5 -нагрівальний елемент; 6 - водяна рубашка; 7 -потік надлишкового мулу; 8 - $\epsilon$ ність для збору мулу; 9 -температурний сенсор;

10 - потік біогазу; 11 - водяний газгольдер. 
На початку кожного циклу компоненти субстрату подавались до реактору, після чого кран герметично закривався. Робочу суміш нагрівали до 35$37^{\circ} \mathrm{C}$ за допомогою нагрівального тену, який, за необхідністю, включався автоматично. Стабільна температура робочої суміші забезпечувалась водяною рубашкою з температурним сенсором. Перемішування субстрату здійснювалося за допомогою автоматичної мішалки періодичної дії. Об'єм біогазу, що виділявся, збирався та вимірювався у водяному газгольдері загальним об'ємом 5 дм³.

Для визначення значення $\mathrm{pH}$ реакційного середовища використовувався рН-метр Hanna HI2210 3 діапазоном рН від -2 до $16 \pm 0,01$ од. $\mathrm{pH}$ та температури від $-0,9$ до $120 \pm 0,5^{\circ} \mathrm{C}$. Кількість метану у біогазі визначалася за допомогою сигналізаторуексплозиметру термохімічного СТХ-17-90 3 діапазоном вимірювань 00,0 - 99,9\% НКПР. Показник ХСК визначався відповідно до стандарту КНД 211.1.4.02195. «Методика визначення хімічного споживання кисню (ХСК) в поверхневих і стічних водах». Кількість загального азоту визначалась відповідно до стандарту КНД 211.1.4.031-95 «Методика титрометричного визначення загального азоту в стічних водах». Кількість ЛЖК (летких жирних кислот) визначалась відповідно до «Методики вимірювань масових концентрацій жирів методом тонкошарової хроматографiï».

У ході роботи проведено дослідження анаеробного зброджування стічної води м'ясопереробного підприємства 3 різним ваговим співвідношенням компонентів субстрату (табл.1). Перші три субстрати є моносубстратами (S1,S2, S3) та складаються окремо із стічної води м'ясопереробного підприємства після етапу механічного очищення, 3 гною ВРX 3 солом'яною підстилкою та рисової лузги після очищення рису. Інші субстрати є сумішами та складаються 3 різних компонентів ваговому співвідношенні гною та рисової лузги 3:1 (S4), 1:1 (S5), 1:3 (S6).

До кожного субстрату додано надлишковий мул (затравка) у об'ємі 0,5 л від попереднього анаеробного зброджування гною ВРХ 3 додаванням звичайної води, в якому присутні всі необхідні мікробіальні співтовариства для початку ферментації та деструкції органічних речовин. Дослідження були проведені при підтриманні температури робочої суміші на рівні $35-36^{\circ} \mathrm{C}$. Значення окисно-відновного потенціалу змінювалось у діапазоні від $-260 \ldots-140$ мВ та нижче, що є оптимальними умовами при анаеробній трансформації органічних речовин [7]. Зброджування кожного з субстратів проводилось протягом 10 днів.

\section{Результати досліджень}

За результатами досліджень коливання рівня pH під час анаеробного зброджування різних субстратів відбувалось у діапазоні від 6,2 од. $\mathrm{pH}$ у субстраті S2 (гній BPX) до 7,3 од.pH у субстраті S1 (CB), всі субстрати характеризувались оптимальним рівенем рН для функціонування мікробіального співтовариства. Після закінчення 10денного циклу зброджування, у субстратах спостерігалось зменшення вмісту сухих речовин приблизно у 2 рази, найбільший показник видалення сухих речовин зареєстрований у субстраті S1 (CB) - 56\% та у змішаному субстраті S6 (1г.:3р.л.) - 54 \%. Також відмічено зменшення показника ХПК субстратів до та після зброджування, що відображає ступінь деструкції органічних речовин, а саме: S1 (CB) - 42\%, S2 (гній BPX) $58 \%$, S3 (рисова лузга) - 37\%, S4 (3г.:1р.л.) - 66\%, S5 (1г.:1р.л.) - 64\% та S6 (1г.:3р.л.) - 65\%. Кількість загального азоту у субстратах після анаеробного зброджування практично не змінилась, відмічено незначне зменшення загального азоту у всіх субстратах у межах 5-10\%. Вміст ЛЖК після анаеробного зброджування у субстратах S2 (гній ВPX), S4 (3г.:1р.л.), S5 (1г.:1р.л.) та S6 (1г.:3р.л.) зменшився на 49\%, 55\%, 61 та 54\% відповідно. У субстратах S1 (CB) та S3 (рисова лузга) спостерігалося накопичення ЛЖК, тобто збільшення їх кількості на 5\% та 20\% відповідно, що свідчить про сповільнення реакцій анаеробного зброджування. Зміни фізико-хімічних показників досліджених субстратів до та після зброджування у анаеробному біорекакторі наведені у табл. 2 .

Відповідно до динаміки інтенсивності виділення біогазу досліджуваними субстратами, зразки S4 (3г.:1р.л.) та S2 (гній ВРX) продемонстрували найвищу активність бактерій у перший день, виділення біогазу становило 8,04 дм та 6,43 дм ${ }^{3}$. Найнижча активність бактерій в перший день зброджування відмічена у S1 (CB) - 1,22 дм та S3 (рисова лузга) 0,33 дм $^{3}$ п причини недостатньої кількості бактерій у субстратах на початку ферментації, у складі інших субстратів присутня значна частка гною BPX з наявними видами метаногенних бактерій (Methanococcus, Methanobacteriales, Methanomicrobiales, Methanosarcina and Methanosaeta) [8]. Найкращими результатами виділення біогазу протягом 10денного терміну характеризуються субстрати S4 (3г.:1р.л.) - 8,04 дм ${ }^{3}$

Таблиця 1

Характеристика складу субстратів

\begin{tabular}{|c|c|c|c|c|c|c|c|c|}
\hline \multirow{2}{*}{\multicolumn{2}{|c|}{ Показник }} & \multirow{2}{*}{$\begin{array}{l}\text { Од. } \\
\text { вимір. }\end{array}$} & \multirow[t]{2}{*}{ CB (S1) } & \multirow{2}{*}{$\begin{array}{c}\text { Гній } \\
\text { BPX (S2) }\end{array}$} & \multirow{2}{*}{$\begin{array}{c}\text { Рисова } \\
\text { лузга } \\
\text { (S3) }\end{array}$} & \multicolumn{3}{|c|}{$\begin{array}{l}\text { Вагове співвідношення } \\
\text { гній ВРХ : рисова лузга }\end{array}$} \\
\hline & & & & & & $3: 1$ (S4) & $1: 1$ (S5) & $1: 3$ (S6) \\
\hline \multirow{3}{*}{ Відходи } & $\overline{~ \Gamma .}$ & "кГ & 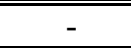 & 7,73 & 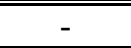 & 3,52 & 2,38 & 1,37 \\
\hline & р.Л. & Кг & - & - & 5,3 & 1,28 & 2,52 & 3,41 \\
\hline & $\overline{\mathrm{CCB}}$ & "л & 28,9 & 20 & 20 & 20 & 20 & 20 \\
\hline \multicolumn{2}{|c|}{ Надлишковий мул } & "л & 0,5 & 0,5 & 0,5 & 0,5 & 0,5 & 0,5 \\
\hline \multicolumn{2}{|c|}{ "Вміст сухих речовин } & $\%$ & 5,8 & 111,65 & 25,2 & 15,1 & 18,6 & 20,4 \\
\hline
\end{tabular}

де СВ - стічні води м'ясопереробного підприємства, г. - гній великої рогатої худоби,

р.л. - рисова лузга 
Фізико-хімічні показники субстратів до та після анаеробного зброджсування

Таблиця 2

\begin{tabular}{|c|c|c|c|c|c|c|c|c|}
\hline \multirow{2}{*}{ Показники } & \multirow{2}{*}{ Од. } & \multirow{2}{*}{\begin{tabular}{|c|} 
Зразки до (a) \\
та після (б) \\
зброджуван- \\
ня \\
\end{tabular}} & \multirow{2}{*}{$\begin{array}{l}\text { CB } \\
(\mathbf{S} 1)\end{array}$} & \multirow{2}{*}{$\begin{array}{l}\text { Гній } \\
\text { BPX } \\
\text { (S2) }\end{array}$} & \multirow{2}{*}{$\begin{array}{c}\text { Рисова } \\
\text { лузга } \\
\text { (S3) }\end{array}$} & \multicolumn{3}{|c|}{$\begin{array}{l}\text { Вагове співвідношення } \\
\text { гній ВРХ : рисова лузга }\end{array}$} \\
\hline & & & & & & $3: 1$ (S4) & 1:1 (S5) & $1: 3$ (S6) \\
\hline \multirow{2}{*}{$\mathrm{pH}$} & \multirow{2}{*}{ - } & $\mathrm{a}$ & 7,27 & 6,24 & 6,72 & 6,41 & 6,53 & 6,43 \\
\hline & & 6 & 6,81 & 6,22 & 6,65 & 6,51 & 6,47 & 6,41 \\
\hline \multirow{2}{*}{ Вміст сух.p. } & \multirow{2}{*}{ мг/л } & $\mathrm{a}$ & 5,8 & 11,65 & 25,2 & 15,1 & 18,6 & 20,4 \\
\hline & & $\overline{6}$ & 3,3 & 5,7 & 11,25 & 7,9 & 9,2 & 11,0 \\
\hline \multirow{2}{*}{ ХПК } & \multirow{2}{*}{ мг/л } & $\overline{\mathrm{a}}$ & 1270 & 4455 & 1410 & 2892 & 2620 & 2078 \\
\hline & & $\overline{6}$ & 737 & 1871 & 888 & 938 & 943 & 935 \\
\hline \multirow{2}{*}{ Загальний азот } & \multirow{2}{*}{ мг/л } & $\mathrm{a}$ & 102 & 458,2 & 108,3 & 173 & 228 & 157 \\
\hline & & 6 & 98,7 & 439 & 106 & 172,5 & 224,7 & 156,4 \\
\hline \multirow{2}{*}{ Леткі жирні кислоти } & \multirow{2}{*}{ мг/л } & $\mathrm{a}$ & 165 & 427 & 311,8 & 328 & 334,3 & 372,6 \\
\hline & & 6 & 174 & 218,4 & 373 & 148,5 & 164 & 171,7 \\
\hline $\begin{array}{l}\text { Ступінь деструкції ор } \\
\text { гнічних речовин }\end{array}$ & $\%$ & - & 42 & 58 & 37 & 66 & 64 & 65 \\
\hline
\end{tabular}

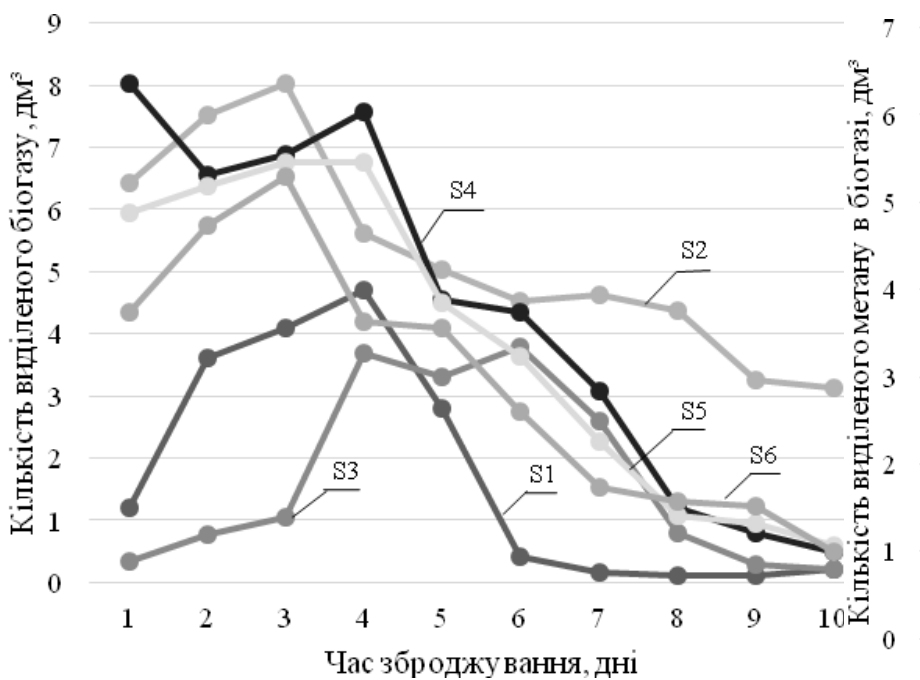

Рис.2 - Динаміка інтенсивності виділення біогазу

S1 - субстрат складається з стічної води м'ясопереробного підприємства після етапу механічного очищення, $S 2$ - з гною $B P X$ з солом'яною підстилкою, S3 - з рисової лузги після очищення рису, S4, S5, S6 субстрати є сумішами та складаються $з$ різних компонентів ваговому співвідноменні гною та рисової лузги $S 4$ - 3:1, S5 - 1:1, S6 - 1:3.

на 1ий день, S2 (гній ВPX) - 8,03 дм³ на 3ій день, S5 (1г.:1р.л.) - 6,76 дм ${ }^{3}$ на 3ій день, S6 (1г.:3р.л.) - 6,52 дм $^{3}$ на Зій день зброджування. За підсумковими результатами кількість виділеного біогазу за весь період становить: S2 (гній ВРX) - 52,53 дм³, $\mathrm{S} 4$ (3г.:1р.л.) - 43,54 дм³, S5 (1г.:1р.л.) - 38,9 дм³, S6 (1г.:3р.л.) 32,2 дм $^{3}, \mathrm{~S} 1$ (CB) - 17,38 дм ${ }^{3}, \mathrm{~S} 3$ (рисова лузга) $-16,86$ дм $^{3}$ відповідно. Результати досліджень динаміки утворення біогазу 3 різних субстратів наведено на рис. 2.

Об'єм виділеного метану у складі біогазу за досліджуваний термін становить: S2 (гній ВРX) 35,9 дм $^{3}, \mathrm{~S} 4$ (3г.:1р.л.) - 35,2 дм³, S5 (1г.:1р.л.) - 32,1 дм ${ }^{3}, \mathrm{~S} 6$ (1г.:3р.л.) - 26,7 дм ${ }^{3}, \mathrm{~S} 1(\mathrm{CB})-14,8$ дм $^{3}, \mathrm{~S} 3$

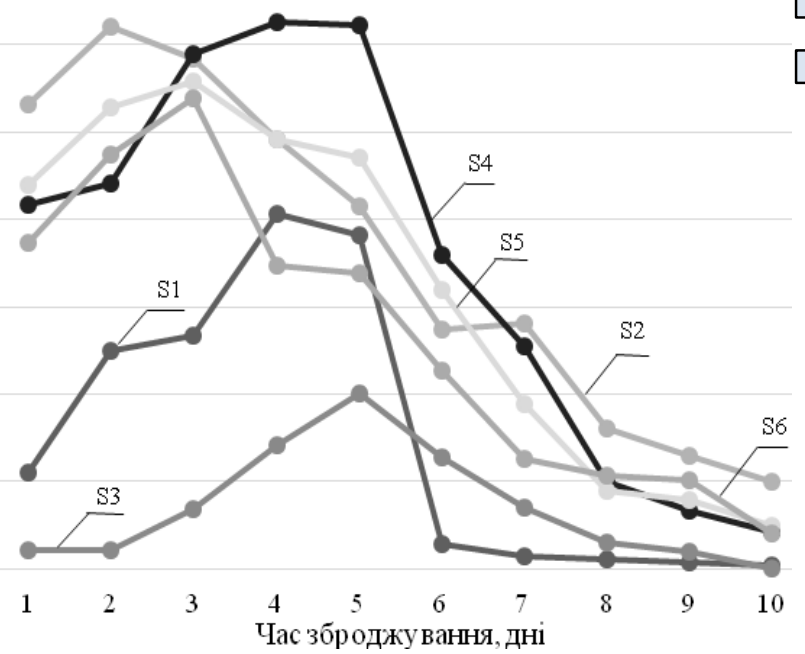

Рис.3 - Динаміка інтенсивності виділення утвореного метану у біогазу

S1 субстрат складається з стічної води м'ясопереробного підприємства після етапу механічного очищення, $S 2$ з гною $B P X$ з солом'яною підстилкою, $S 3$ рисової лузги після очищення рису, субстрати S4, S5, S6 є сумішами та складаються з різних компонентів ваговому співвідноченні гною та рисової лузги $S 4-3: 1, S 5-1: 1, S 6-1: 3$.

(рисова лузга) - 7 дм³ відповідно. Динаміка інтенсивності виділення метану у результаті роботи метаногенних бактерій під час анаеробного зброджування наведена на рис.3.

\section{Висновки}

У ході роботи виконано дослідження впливу рисової лузги на процес анаеробного зброджування відходів м'ясопереробної промисловості у вигляді промислових стічних вод та гною ВРХ 3 території передзабійного утримання тварин протягом 10 днів. Дослідження зміни фізико-хімічних показників субстратів показали, що рівень рН субстратів протягом 
зброджування залишався у межах оптимальних умов для метаногенних мікроорганізмів, вміст сухих речовин після ферментації у всіх зразках зменшився у 2 рази, кількість загального азоту у субстратах зменшилася на 5-10\%. Також було зареєстровано незначне накопичення проміжних компонентів зброджування - летких жирних кислот, у субстратах S1 (CB) - 5\% та S3 (рисова лузга) - 20\%, що свідчить про збій у процесі змін фаз анаеробного зброджування. Зброджування субстратів характеризується різним ступенем деструкції органічних речовин, що залежить від компонентів субстрату, таким чином діапазон біорозкладання органічних речовин змінюється від 37\% у субстраті S3 (рисова лузга) до 66\% у субстраті S4 (Зг.:1р.л.). За результатами дослідження газоутворюючих властивостей субстратів встановлено, що за період ферментації найбільша кількість біогазу утворюється субстратами S2 (гній ВРX) - 52,53 дм ${ }^{3}$ та S4 $-43,54$ дм $^{3}$, загальний вміст метану в зразках біогазу становив S2 - 35,9 дм ${ }^{3}, \mathrm{~S} 4-35,2$ дм $^{3}$.

Результати порівняльного аналізу показників до та після зброджування сумішей субстратів 3 різним ваговим співвідношенням гною ВРХ та рисової лузги (S4 - 3:1, S5 - 1:1, S6 - 1:3) свідчать, що ефективність біорозкладання органічних речовин у всіх трьох субстратах становить $65 \pm 1 \%$; кількість виділеного біогазу: S4(3г.:1р.л.) - 43,54 дм³ $\mathrm{S} 5$ (1г.:1р.л.) 38,9 дм $^{3}$, S6 (1г.:3р.л.) - 32,2 дм ${ }^{3}$, кількість метану у виділеному біогазі за період дослідження становить S4 (3г.:1р.л.) - 35,2 дм ${ }^{3}$, S5 (1г.:1р.л.) - 32,1 дм ${ }^{3}$, S6 (1г.:3р.л.) - 26,7 дм³. Таким чином, результати дослідження спільної ферментації рисової лузги та відходів м'ясопереробних виробництв у анаеробному біореакторі демонструють ефективність обраного методу утилізації, що забезпечує високі показники деструкції органічних речовин, виходу біогазу з високим вмістом метану та стабільність протікання анаеробних реакцій.

\section{ЛІТЕРАТУРИ}

1. Статистичний шорічник Украӥни, 2014 рік [Текст] : статистичний щорічник / Державна служба статистики Украйни / О. А. Вишневська (від. За вип). - К.: Держаналітінформ., 2015. - 585 с.

2. Wang, Q.; Kuninobu, M.; Ogawa, H.; Kato, Y. Degradation of volatile fatty acids in highly efficient anaerobic digestion. Biomass Bioenergy 1999, 16, pp. 407-416.

3. Rajeshwari K.V., Balakrishnan M., Kansal A., Kusum Lata and Kishore V.V.N., State-of-the-art of Anaerobic Digestion Technology for Industrial Wastewater Treatment, Renewable and Sustainable Energy Reviews, 2000, Vol. 4, pp. 135-156.

4. V. ReginattoI, R. M. TeixeiraI; F. PereiraI; W. Schmidelli; A. Furigo JrI; R. MenesII; C. EtchebehereII; H. M. Soares Anaerobic ammonium oxidation in a bioreactor treating slaughterhouse wastewater, Brazilian Journal of Chemical Engineering 2005, vol.22 no.4, http://dx.doi.org/10.1590/S0104-66322005000400012.

5. Viet N.T. Sustainable Treatment of Rubber Latex Processing Wastewater-the UASB-System Combined with Aerobic Post-Treatment, Thesis, The Wageningen University, Wageningen, The Netherlands, 1999) pp. 1-17.

6. Malashenko Y.R. Medium redox-potential during cultivation of mehtanogenic community / J.R. Malashenko, D.V. Chernyshenko, Y.N. Danko, L.S. Yastremskaya, V.I Karpenko: Symposium on biotechnology for fuel and chemicals (8-12 may 1989): Abstr. - ColoradoSpring. - USA. - 1989. - P.82.

7. Sharon McHugh, Micheal Carton, There'se Mahony, Vincent O'Flaherty Methanogenic population structure in a variety of anaerobic bioreactors; FEMS Microbiology Letters 219 (2003) 297^304 doi:10.1016/S0378-1097(03)00055-7.

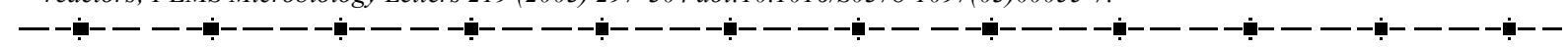

KRUSSIR G. Dr., prof, HEINZ LEUENBERGER Dr., Prof., CHERNYSHOVA O. Odessa National Academy of Food Technologies, Odessa

\section{INVESTIGATION OF JOINT UTILIZATION OF MEAT PROCESSING WASTE} AND RICE HUSK BY ANAEROBIC DIGESTION

\section{Abstract}

The main position of the Environmental Protection Policy strategy and environment for sustainable development of the country provide a comprehensive solution to the problems of sustainable development of the economy and improvement of the environment. Current rate of development of grain-processing and meat-processing industries makes the issue of effective and cost-effective ways of waste disposal more actionable. According to the conceptual principles of the re-processing of raw waste recycling waste meat processing industry, which includes waste water, which are formed directly in the production of meat and cattle manure requires special attention. Biotechnological methods of processing are considered promising direction of recycling food production wastes. One of such methods is anaerobic digestion, which is continuous multi-component process of organic materials transformation to finished products - biogas containing methane, water vapor and carbon dioxide, which is provided by a microbial communities activity.

The aim of this study was to investigate the joint utilization of rice husk, manure and meat processing manufacture sewage by anaerobic digestion in a laboratory anaerobic batch UASB bioreactor (Upflow Anaerobic Sludge Blanket reactor) for 10 days. During the study, resulting in anaerobic reactions were identified parameters of influence of the substrate composition on the efficiency of decomposition of organic matter, biogas and methane yield. A series of experiments anaerobic fermentation of substrates was carried out with different weight ratio of manure, waste water and rice husk at mesophilic temperature conditions $\left(36 \pm 1^{\circ} \mathrm{C}\right)$. To determine the optimal weight proportions of components in mixed waste as a substrate for fermentation in an anaerobic bioreactor, we assessed the degree of organic matter degradation in manure, rice husks and waste waters and estimated negative impact of volatile fatty acids in the course of anaerobic reactions. After benchmarking fermentation mono-substrates and mixtures, it was proved the effectiveness of the use of mixed substrates for methane and to increase the degree of biodegradability of organic substances waste.

Keywords: anaerobic digestion, waste, rise husk, cattle manure, biogas. 


\title{
REFERENCES
}

1. Статистичний щорічник Украйни, 2014 рік [Текст] : статистичний щчорічник / Державна служба статистики Украӥни / О. А. Вишневська (від. За вип). - К.: Держаналітінформ., 2015. - 585 c.

2. Wang, Q.; Kuninobu, M.; Ogawa, H.; Kato, Y. Degradation of volatile fatty acids in highly efficient anaerobic digestion. Biomass Bioenergy 1999, 16, pp. 407-416.

3. Rajeshwari K.V., Balakrishnan M., Kansal A., Kusum Lata and Kishore V.V.N., State-of-the-art of Anaerobic Digestion Technology for Industrial Wastewater Treatment, Renewable and Sustainable Energy Reviews, 2000, Vol. 4, pp. 135-156.

4. V. ReginattoI, R. M. TeixeiraI; F. PereiraI; W. SchmidellI; A. Furigo JrI; R. MenesII; C. EtchebehereII; H. M. Soares Anaerobic ammonium oxidation in a bioreactor treating slaughterhouse wastewater, Brazilian Journal of Chemical Engineering 2005, vol.22 no.4, http://dx.doi.org/10.1590/S0104-66322005000400012.

5. Viet N.T. Sustainable Treatment of Rubber Latex Processing Wastewater-the UASB-System Combined with Aerobic PostTreatment, Thesis, The Wageningen University, Wageningen, The Netherlands, 1999) pp. 1-17.

6. Malashenko Y.R. Medium redox-potential during cultivation of mehtanogenic community / J.R. Malashenko, D.V. Chernyshenko, Y.N. Danko, L.S. Yastremskaya, V.I Karpenko: Symposium on biotechnology for fuel and chemicals (8-12 may 1989): Abstr. - Colorado-Spring. - USA. - 1989. - P.82.

7. Sharon McHugh, Micheal Carton, There'se Mahony, Vincent O'Flaherty Methanogenic population structure in a variety of anaerobic bioreactors; FEMS Microbiology Letters 219 (2003) 297^304 doi:10.1016/S0378-1097(03)00055-7.

Надійшла 23.01.2016. До друку 13.02.2016

Адреса для переписки:

вул. Канатна, 112, м. Одеса, 65039

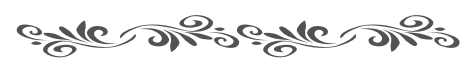

УДК 664.785

С.М. СОЦ, канд. техн. наук., доцент, В.Т. ГУЛАВСЬКИЙ, канд. техн. наук., I.О. КУСТОВ, канд. техн. наук., асистент

\section{БОРОШНО ТА ВИСІВКИ - НОВІ ПРОДУКТИ ІЗ ГОЛОЗЕРНОГО ВIВСА}

\begin{abstract}
Анотація
Аналіз існуючих в Україні традиційних технологій переробки зернових і бобових культур в крупи і круп'яні продукти показує, що на сьогоднішній день переважна більшість діючих технологій була розроблена 20-30 років тому і передбачає використання значної кількості систем і операчій, особливо лущення та шліфування при реалізачії яких передбачається застосування машин типу ЗШН, що у сукупності передбачає значну енергоємність прочесу. При иьому асортимент круп'яної продукиії, що виробляється більшою мірою залишається стабільним і включає крупи подрібнені та неподрібнені, пластівиі та борошно. У більшості сучасно орієнтованих країн протягом останніх років відбувається перехід до нових скорочених і більш енергоефективних технологій переробки зернових культур в крупи та круп'яні продукти при цьому відбувається також впровадження нових високопродуктивних сортів зернових культур. Особливе місие при иьому займають голозерні форми традиційних культур - вівса та ячменю. На основі иієї сировини відбувається розиирення асортименту, збільшення виходу готової продукиії, підвищення їі харчової иінності. В нашій країні вітчизняними селекціонерами також отримані високопродуктивні сорти традиційних круп'яних культур, однак необхідно звернути увагу на те, щзо, наприклад, нові сорти пшеничі переважною мірою за анатомічною і морфологічною будовою є аналогічними $і$ їх переробка не потребує суттєвої перебудови технологічного процесу, але такі культури як голозерний овес чи голозерний ячмінь переробляти відповідно до існуючих режимів і структури складно, ие призводить до неповного використання потенціалу переробляємої сировини та нівелює усі ї̈ переваги над традииійною. Враховуючи це актуальною проблемою для вітчизняного круп'яного виробництва є розробка нових енергоефективних технологій, розширення існуючого асортименту продуктів та підвищення ї̈ харчової чінності. В одеській національній академії харчових технологій на кафедрі технології переробки зерна проводяться дослідження метою яких є розробка науково обтрунтованих технологій переробки нових видів зернової сировини і ї̈ впровадження у вітчизняне круп'яне виробничтво. У даній статті наведено структуру та основні етапи переробки голозерного вівса в круп'яні продукти. Наведено основні відмінності застосування голозерного вівса як сировини для виробництва круп'яних продуктів в порівнянні із плівковими формами круп'яного вівса. Проаналізовано можливості використання голозерного вівса для розширення асортименту вівсяних продуктів за рахунок виробництва круп пропарених, не пропарених, круп плющених, пластівців та борощна. При изьому прочес виробництва розглянутої продукції характеризується скороченою структурою технологічного процесу, продукти в порівнянні із класичними мають підвищений вихід та якість.

Ключові слова: крупа вівсяна, воднотеплова обробка, очищення зерна від домішок, пропарювання, плющені продукти, вівсяне борочно, голозерний овес, скорочена структура технологічного процесу, підвищення харчової цінності.
\end{abstract}

Продукти переробки вівса в Україні за останні десятиліття стали традиційними для більшості населення нашої країни. Основою високого попиту на вівсяну продукцію є висока харчова цінність, яка формується за рахунок високого вмісту білка, повноцінності амінокислотного складу, наявності високого вмісту жирів та ненасичених жирних кислот, вмісту харчових волокон, особливо $\beta$-глюканів, вітамінів т.д
Відповідно до Правил ведення і організації технологічного процесу на круп'яних заводах овес переробляють в крупи неподрібнені, плющені, пластівці «Геркулес», «Пелюсткові», «Екстра». Сировиною для виробництва зазначеного асортименту круп та круп'яних продуктів є зерно плівчастого вівса продовольчих потреб, I-III клас відповідно до ДСТУ 49632008. Особливістю зазначених сортів вівса $є$ висока 